AIAA- 2000-2972

\title{
THERMAL CHARACTERIZATION OF LI-ION CELLS USING CALORIMETRIC TECHNIQUES
}

\author{
E. Peter Roth \\ Lithium Battery R\&D Dept. 2521 \\ Sandia National Laboratories, \\ P.O. Box 5800 MS0613, \\ Albuquerque, NM 87185-0613
}

\begin{abstract}
The thermal stability of $\mathrm{Li}$-ion cells with intercalating carbon anodes and metal oxide cathodes was measured as a function of state of charge and temperature for two advanced cell chemistries. Cells of the 18650 design with $\mathrm{Li}_{x} \mathrm{CoO}_{2}$ cathodes (commercial Sony cells) and $\mathrm{Li}_{x} \mathrm{Ni}_{0.8} \mathrm{Co}_{0.2} \mathrm{O}_{2}$ cathodes were measured for thermal reactivity. Accelerating rate calorimetry (ARC) was used to measure cell thermal runaway as a function of state of charge (SOC), microcalorimetry was used to measure the time dependence of thermal output, and differential scanning calorimetry (DSC) was used to study the thermal reactivity of the individual components. Thermal decomposition of the anode solid electrolyte interphase (SED) layer occurred at low temperatures and contributes to the initiation of thermal runaway. Low temperature reactions from $40^{\circ} \mathrm{C}-70^{\circ} \mathrm{C}$ were observed during the ARC runs that were SOC dependent. These reactions measured in the microcalorimeter decayed over time with power-law dependence and were highly sensitive to SOC and temperature. ARC runs of aged and cycled cells showed complete absence of these low-temperature reactions but showed abrupt exothermic spikes between $105-135^{\circ} \mathrm{C}$. These results suggest that during aging the anode SEI layer is decomposing from a metastable state to a stable composition that is breaking down at elevated temperatures.
\end{abstract}

\section{INTRODUCTION}

Lithium-ion batteries (organic liquid electrolyte) have an advanced battery chemistry that exhibits superior performance characteristics to virtually all other rechargeable battery systems at room temperature. Consequently, this system is experiencing unparalleled growth and growth potential. These batteries demonstrate enhanced safety over the lithium metal systems that are subject to internal short circuits due to dendrite formation at the lithium metal surface after repeated cycling. The $\mathrm{Li}$-ion cells use a carbon matrix for the intercalation of the $\mathrm{Li}$ ions at the anode in the charged state and use a metal oxide for $\mathrm{Li}$ ion intercalation at the cathode in the discharged state. This interchange of $\mathrm{Li}$ ions is referred to as a "rocking chair" cell. The formation of the active layers of each electrode material requires the use of polymeric binder material and conductivity enhancing additives. The electrolytes usually consist of a mixture of carbonatebased solvents and a Li salt. The lifetime and safety of these cells depends on the thermal stability of these active layer mixtures in the presence of electrolyte solution.

The purpose of this study was to identify the thermal response of these constituent cell materials, their contribution to the overall cell thermal performance and the effects of aging on this behavior. Calorimetric techniques were used as a sensitive measure of these thermophysical properties.

\section{EXPERIMENTAL}

Full cells were measured (commercial Sony cells US18650S STG) which had nominal 1.2 Ah capacity at $1 \mathrm{C}$ rate. The Sony-type cells consist of $\mathrm{Li}_{\mathrm{x}} \mathrm{CoO}_{2}$ as the active cathode and $\mathrm{Li}_{\mathrm{x}} \mathrm{C}_{6}$ intercalating carbon as the active anode using PVDF as the binder material. ${ }^{1}$ The electrolyte is a mixture of carbonatebased solvents with $\mathrm{LiPF}_{6}$ as the ionic salt. These cells were cycled using an Arbin battery tester (Arbin Corp., College Station, Texas) and the charge states set based on an initial calibration of these cells that determined cell voltage as a function of SOC.

The cells with $\mathrm{Li}_{\mathrm{x}} \mathrm{Ni}_{0.8} \mathrm{Co}_{0.2} \mathrm{O}_{2}$ cathodes were prepared in the 18650 configuration and had a nominal capacity of $0.9 \mathrm{Ah}$ ( $1 \mathrm{C}$ rate). These cells are referred to as GENI Cells and were prepared as part of the DOE Advanced Technology Development 


\section{DISCLAIMER}

This report was prepared as an account of work sponsored by an agency of the United States Government. Neither the United States Government nor any agency thereof, nor any of their employees, make any warranty, express or implied, or assumes any legal liability or responsibility for the accuracy, completeness, or usefulness of any information, apparatus, product, or process disclosed, or represents that its use would not infringe privately owned rights. Reference herein to any specific commercial product, process, or service by trade name, trademark, manufacturer, or otherwise does not necessarily constitute or imply its endorsement, recommendation, or favoring by the United States Government or any agency thereof. The views and opinions of authors expressed herein do not necessarily state or reflect those of the United States Government or any agency thereof. 


\section{DISCLAIMER}

Portions of this document may be illegible in electronic image products. Images are produced from the best available original document. 
(ATD) program. The cathodes and MCMB carbon anodes were prepared using PVDF binder and the cell electrolyte was $(1 \mathrm{M}) \mathrm{LiPF}_{6} /$ ethylene carbonate (EC): diethylcarbonate (DEC) $(1: 1)$. These cells were cycled and calibrated in the same manner as the Sony cells.

DSC analysis of cell components was performed using a DSC 2920 (TA Instr., New Castle, DE) up to a temperature of $400^{\circ} \mathrm{C}$ in sealed aluminum pans. All samples were measured in the presence of the cell electrolyte. High-pressure stainless steel pans were used for measurements of the electrolyte components. Isothermal microcalorimetry measurements were made of the open circuit cells using a CSC 4400 isothermal microcalorimeter (Calorimetry Sciences Corp., Provo, UT) at $25^{\circ} \mathrm{C}$ and $60^{\circ} \mathrm{C}$. The cells were measured from $0-100 \%$ state of charge (SOC) for periods of up to 800 hours. ARC measurements were performed using an ARC-2000 accelerating rate calorimeter (Columbia Scientific Industries, Austin, TX) using a specially designed holder for the 18650 cells which allowed simultaneous monitoring of cell voltage. The maximum cell temperature was limited to $160^{\circ} \mathrm{C}$ for the initial ARC runs and later limited to $140^{\circ} \mathrm{C}$ for the remainder of the cells. This temperature was above the vent temperature of the cells but below the explosive decomposition temperature that was observed around $200^{\circ} \mathrm{C}$.

\section{RESULTS AND DISCUSSION}

\section{DSC Analysis:}

Full cells that had been electrically cycled were disassembled and the electrodes measured up to $400^{\circ} \mathrm{C}$. Figure 1 shows data for Sony cells disassembled in the fully charged state and in the partially discharged (approximately $50 \%$ SOC). There are three main temperature regions of thermal reactions. A low-temperature region from about $100^{\circ} \mathrm{C}-200^{\circ} \mathrm{C}$ shows an exothermic reaction that has been found to involve SEI decomposition from a metastable species formed during initial cycling to more stable inorganic reaction products followed by further electrolyte reduction. ${ }^{2-4}$ This reaction has been seen to start as low as $80^{\circ} \mathrm{C}$. The exact temperature range of these reactions depends on the particular solvent and salt species used for the electrolyte. An intermediate temperature regime from $200^{\circ} \mathrm{C}-300^{\circ} \mathrm{C}$ shows exothermic behavior resulting from interaction of the Li-intercalated graphite with the electrolyte and the PVDF binder. An endothermic dip in the $250^{\circ} \mathrm{C}-300^{\circ} \mathrm{C}$ range is superimposed on the exotherm

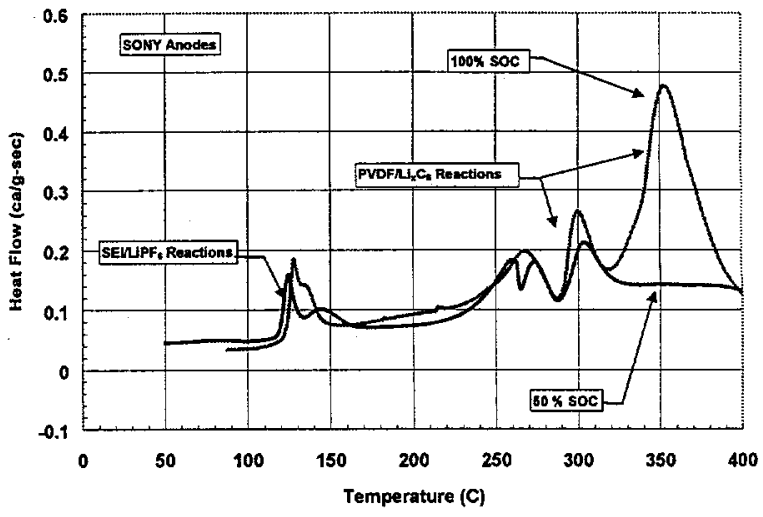

Figure 1. DSC data of Sony anodes at $50 \%$ SOC and $100 \%$ SOC.

and results from venting of evolved gas products from the DSC pans. At the high-temperature range from $300^{\circ} \mathrm{C}-400^{\circ} \mathrm{C}$ the PVDF binder continues reacting with the $\mathrm{Li}$-intercalated graphite. The hightemperature reactions are very state of charge (SOC) dependent as seen in the figure.

The thermal response of the Sony cathodes for disassembled cells at $100 \%$ SOC and $50 \%$ SOC are shown in Figure 2. The cathodes showed the greatest exothermic behavior at temperatures above $200^{\circ} \mathrm{C}$, increasing at the higher SOC. It is believed that this reaction results from metal oxide/PVDF binder reaction and possibly includes oxidation of the electrolyte. The cathodes showed greater reactivity in the charged (delithiated) state. The higher oxidation state of the metal oxide may result in increased electrolyte oxidation and reaction with the binder. The lower temperature reactions are similar to the anode SEI reactions and may result from a cathode SEI layer or anode SEI products transferred to the cathode.

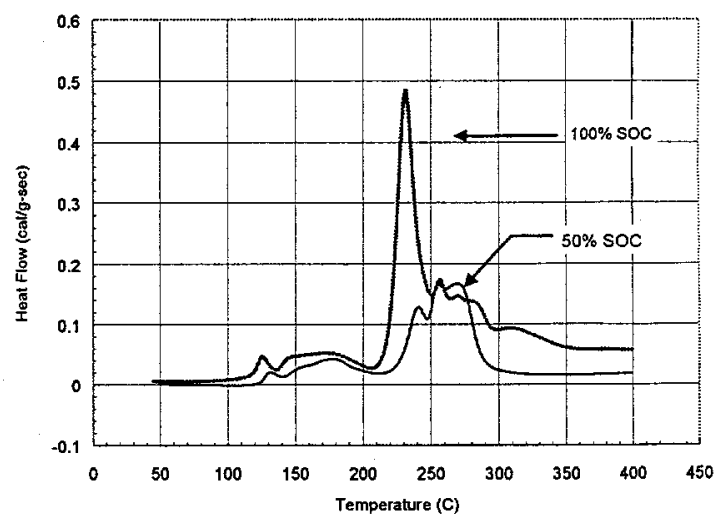

Figure 2. DSC data for Sony cells at $50 \%$ SOC and $100 \%$ SOC. 
Cycled GEN1 cells were disassembled and measured for comparison. The data for the anodes from both Sony and GEN1 cells ( $50 \%$ SOC), shown in Figure 3, exhibited very similar behavior as expected since they have similar intercalating carbon compositions. The exothermic SEI reactions dominated the low-temperature response and were somewhat higher for the material from the GEN1 cells.

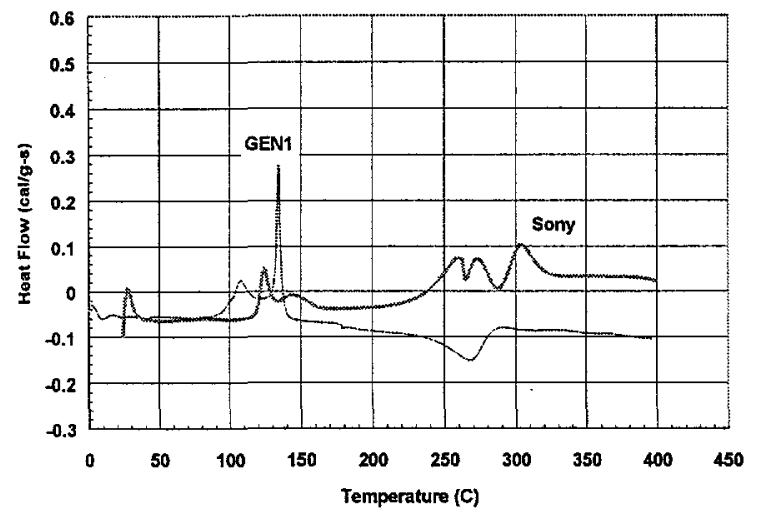

Figure 3. DSC data of GEN1 and Sony anodes at $50 \%$ SOC.

The charge dependence of the GEN1 anodes is shown in Figure 4. As seen for the Sony cells, the anodes become more exothermic at higher SOC for the higher temperature reactions.

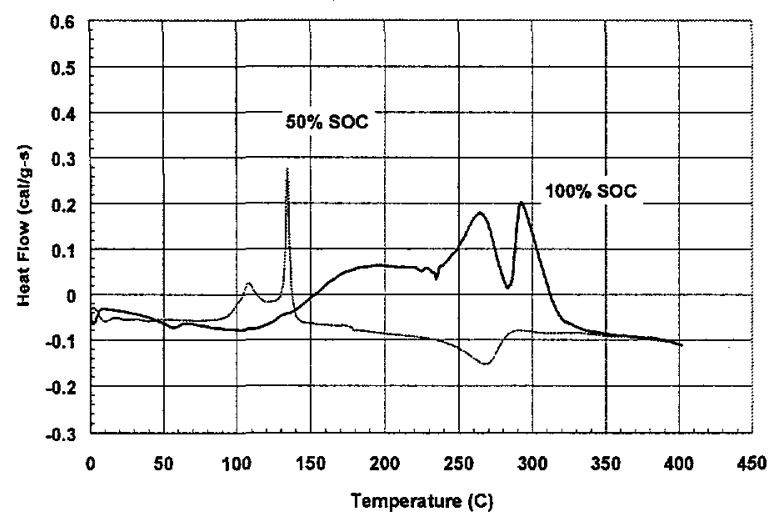

Figure 4. DSC data of GEN1 anodes at 50\% SOC and $100 \%$ SOC.

The data for the GEN1 cathodes ( $50 \%$ SOC) are shown in Figure 5 along with data for the Sony cathodes. The $\mathrm{Li}_{\mathbf{x}} \mathrm{Ni}_{0.8} \mathrm{Co}_{0.2} \mathrm{O}_{2}$ cathodes from the GEN1 cells were markedly more exothermic than the $\mathrm{Li}_{x} \mathrm{CoO}_{2}$ Sony cathodes at similar SOC and the reactions initiated at slightly lower temperature. This increased thermal response has been seen for increasing $\mathrm{Ni}$ content in cathode materials. ${ }^{5}$ No significant thermal output was observed at lower temperatures.

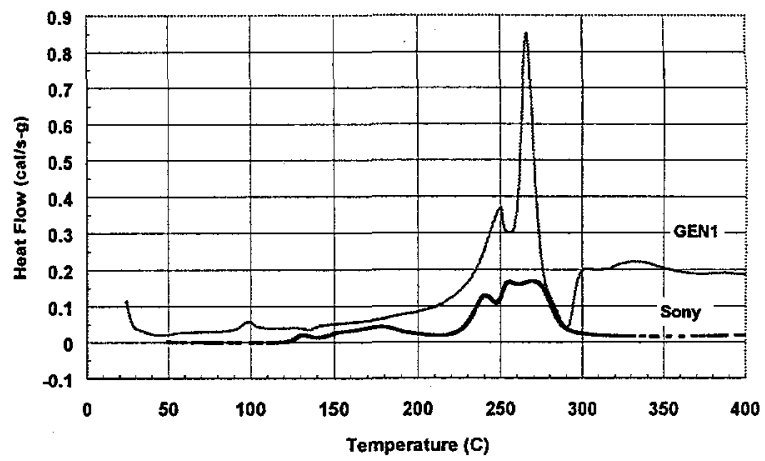

Figure 5. DSC data for GEN1 and Sony cathodes at $50 \%$ SOC.

The SOC dependence was measured at $50 \%$ SOC and $100 \%$ SOC as for the anodes. Figure 6 shows that mid-temperature exotherm increased significantly with increasing SOC. The increasing thermal output of both anodes and cathodes with increasing SOC contributes to the cell reactivity at temperatures above $200^{\circ} \mathrm{C}$. Safety tests of these cells have shown that they react violently beginning at this temperature.

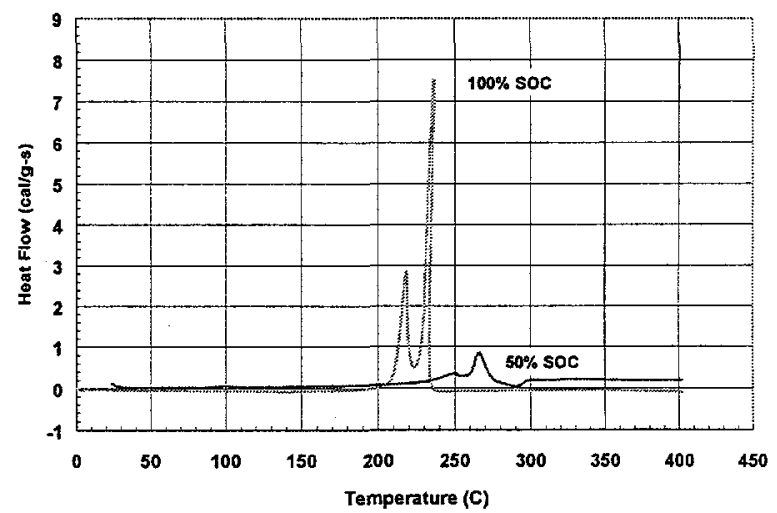

Figure 6. DSC data for GEN1 cathodes at $50 \%$ SOC and $100 \%$ SOC.

Another contributor to the cell thermal response is the electrolyte. Measurements of the electrolyte constituents (EC:DEC, $\mathrm{LiPF}_{6}$, and the full electrolyte solution) were measured in high-pressure DSC pans which contained the gaseous decomposition products up to $300^{\circ} \mathrm{C}$, thus avoiding the confusing endotherm seen for the sealed Al pans. These measurements, Figure 7 , showed that the pure solvent did not 


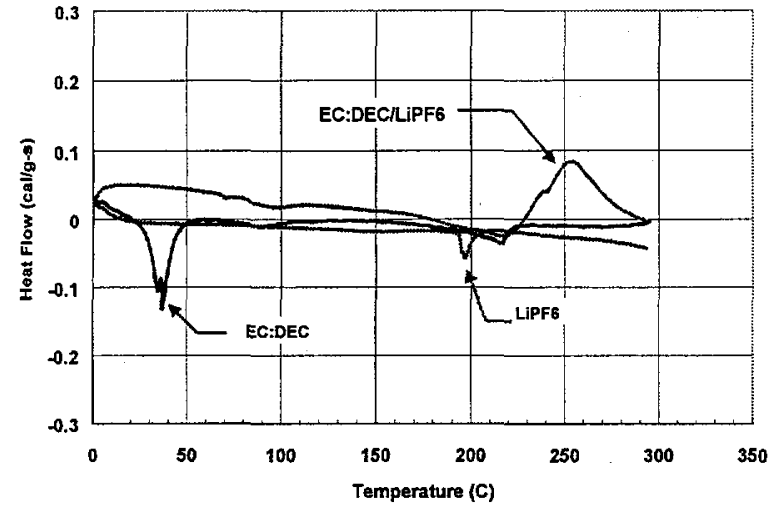

Figure 7. DSC data for electrolyte and electrolyte constituents in high-pressure sealed pans.

undergo any measurable thermal decomposition up to $300^{\circ} \mathrm{C}$. Likewise, the $\mathrm{LiPF}_{6}$ showed only an endothermic decomposition at $190^{\circ} \mathrm{C}$. FTIR analysis of the $\mathrm{LiPF}_{6}$ decomposition products were primarily $\mathrm{PF}_{5}$ and $\mathrm{POF}_{3}$. The full electrolyte solution underwent an exothermic reaction beginning at temperatures above the $\mathrm{LiPF}_{6}$ decomposition temperature, suggesting that the solvent reacts exothermically with the $\mathrm{LiPF}_{6}$ decomposition products. Any remaining electrolyte in the cell thus becomes a contributor to the full cell exothermic reaction.

\section{ARC Analysis:}

ARC runs were performed on Sony and GEN1 cells at several SOCs while monitoring the cell voltages, as shown in Figure 8. The Sony cells showed a strong SOC dependence where the onset of self-generated heating decreased from about $130^{\circ} \mathrm{C}$ for the discharged cell down to below $70^{\circ} \mathrm{C}$ for the fully charged cell. Cell voltages dropped abruptly in

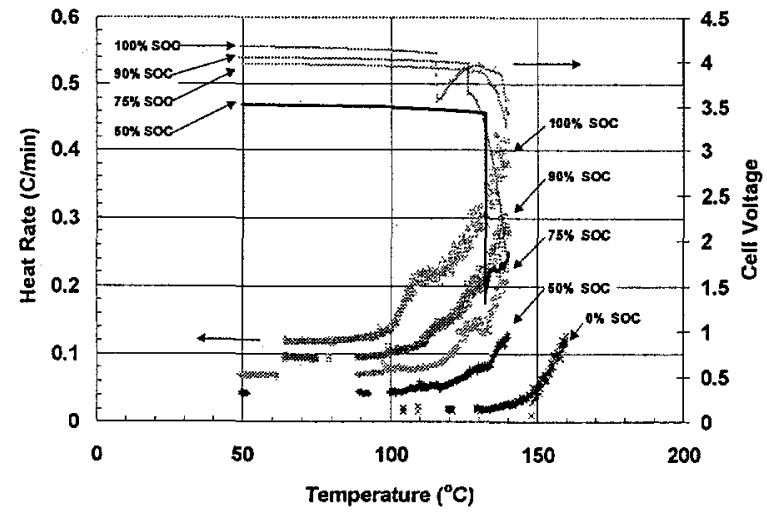

Figure 8. ARC runs of Sony Cells $\left(\mathrm{LiCoO}_{2}\right.$ cathodes ) at increasing SOC (vertically offset). the range $115^{\circ} \mathrm{C}-130^{\circ} \mathrm{C}$ with a corresponding dip in the cell heating rate. These results are due to cell venting and also due to separator melt.

The GEN1 cells (Figure 9) showed similar behavior but with a lower self-generated heating rate for the same SOC. The cells with $50 \%$ or lower SOC showed no accelerating heating while the cells with higher SOC showed accelerating heating only above $75^{\circ} \mathrm{C}$. A low-temperature constant heating rate region was observed whose onset temperature decreased with increasing SOC. This region was separated from the accelerating heat region by about $10^{\circ} \mathrm{C}$. These $\mathrm{Li}_{\mathrm{x}} \mathrm{Ni}_{0.8} \mathrm{Co}_{0.2} \mathrm{O}_{2}$ cells show greater thermal stability than the $\mathrm{Li}_{\mathrm{x}} \mathrm{CoO}_{2}$ cells. This stability may result from differences in mechanical construction rather than intrinsic thermal behavior since the anodes have been shown by DSC to behave similarly to the Sony anodes.

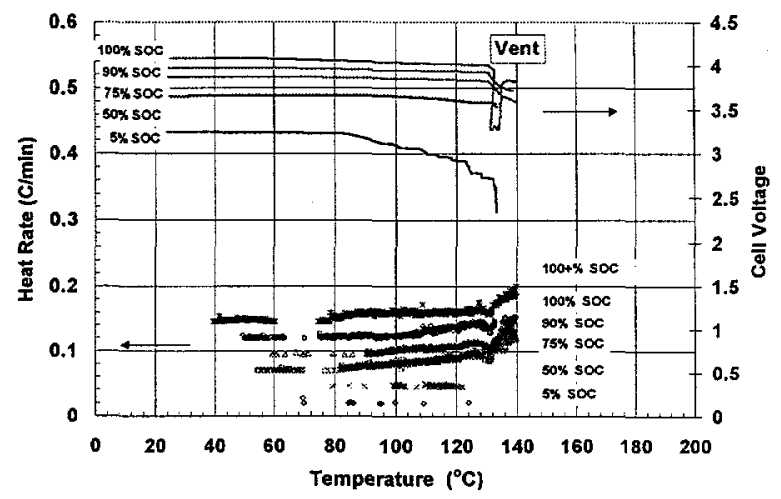

Figure 9. ARC runs of GEN1 Cells $\left(\mathrm{LiNi}_{0.8} \mathrm{Co}_{0.2} \mathrm{O}_{2}\right.$ cathodes ) at increasing SOC (vertically offset).

\section{Microcalorimetry Analysis:}

The low temperature reactions observed during the ARC runs were monitored under more controlled conditions in the isothermal microcalorimeter. Cells were measured at several SOCs at $25^{\circ} \mathrm{C}$ and $60^{\circ} \mathrm{C}$. Figure 10 shows the data for both type of cells at $90 \%$ SOC. Both types of cells exhibited strongly increased heat output with increasing temperature consistent with the behavior observed during both DSC and ARC measurements. However, at these lower temperatures GEN1 cells showed much greater heat output compared to the Sony cells. The heat output decayed following a power-law dependence. Interruption of the microcalorimetry measurements for charge/discharge cycling did not change the thermal output for a given SOC. The cells resumed their thermal decay profile from the time of the interruption. This behavior shows that the heat output 


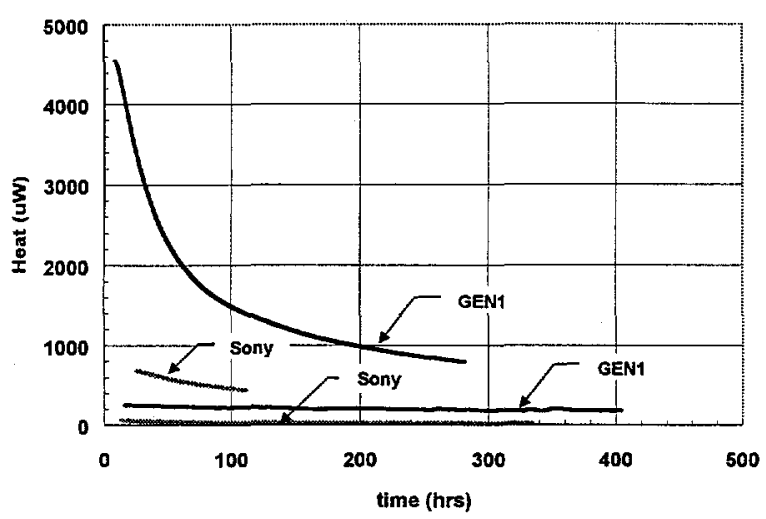

Figure 10. Microcalorimetry results for Sony and GEN1 cells at $25^{\circ} \mathrm{C}$ and $60^{\circ} \mathrm{C}$ ( $\left.90 \% \mathrm{SOC}\right)$.

was not the result of internal equilibration or residual heat decay from cycling. This heat output most likely results from low-rate decomposition and reformation of the SEI layer that was seen previously by DSC. Heat output would also result from oxidation and reduction reactions of the electrolyte, which can impact the cell lifetime and capacity. The differences in reactivity between the Sony and GEN1 cells may result from the different solvents, differences in the morphology of the intercalating carbons and different reactivity of the different metal oxide cathodes. It was already shown that the GEN1 cathodes are more thermally active than the Sony cathodes, especially at higher SOC.

\section{Cell Aging Effects:}

The effects of aging at elevated temperatures were measured by performing ARC runs of thermally aged Sony and GEN1 cells. Figure 11 shows the results for the Sony cells which had been aged for 6 months $/ 25^{\circ} \mathrm{C}, 11$ days $/ 60^{\circ} \mathrm{C}$ and 6 weeks $/ 70^{\circ} \mathrm{C}$. The

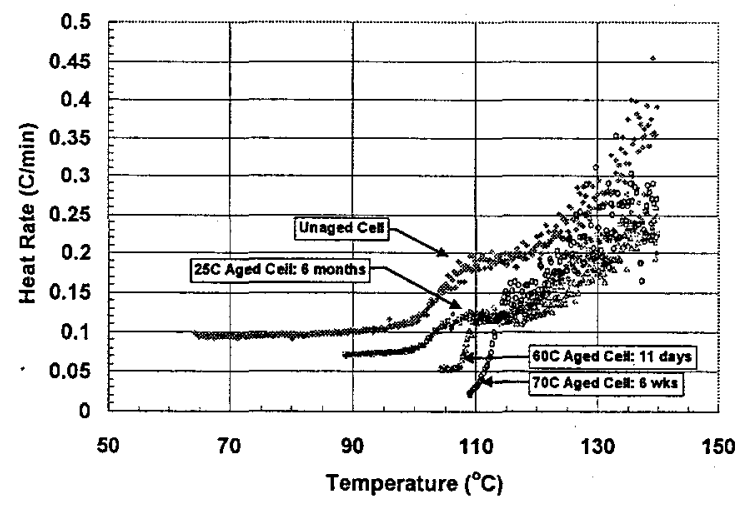

Figure 11. ARC results for aged Sony cells $100 \%$ SOC (vertically offset). cells showed a loss of low-temperature reactivity with increased aging. All cells were measured at $100 \%$ SOC. The data show that aging resulted in loss of the low-temperature heat output with increasing time and temperature. The onset of sustained heat output did not begin until $90^{\circ} \mathrm{C}$ for the 6 month $/ 25^{\circ} \mathrm{C}$ cell compared to reactions starting below $70^{\circ} \mathrm{C}$ for unaged $/ 25^{\circ} \mathrm{C}$ cells. The onset temperature increased to $105^{\circ} \mathrm{C}$ for the 11 day $/ 60^{\circ} \mathrm{C}$ cell and to $110^{\circ} \mathrm{C}$ for the 6 week $/ 70^{\circ} \mathrm{C}$ cell. The cell heating rate responses showed the previously observed "knee" behavior in the $110^{\circ} \mathrm{C}-115^{\circ} \mathrm{C}$ range for all of the cells measured, although the onset of heating was much sharper for the cells aged at elevated temperature. These measurements suggest that the SEI layer is undergoing partial conversion from the metastable species to the stable inorganic species even at these low temperatures. The majority of this conversion takes place relatively quickly (less than two weeks) even at $60^{\circ} \mathrm{C}$ since little further change was noticed for the $70^{\circ} \mathrm{C} / 6$ week cell. The sudden increase in self-heating in the $100^{\circ} \mathrm{C}-110^{\circ} \mathrm{C}$ range suggests that the remaining SEI layer undergoes rapid conversion followed by further reaction of the lithiated anode with the electrolyte with increasing temperature. This rapid increase corresponds closely with the onset of the exothermic peak observed by DSC for these full-cell charged anodes.

A GEN1 cell was aged for 4 weeks at $60^{\circ} \mathrm{C}$. The ARC run (Figure 12) showed no thermal output below $130^{\circ} \mathrm{C}$. Two abrupt increases in heating that quickly decayed below threshold. These GEN1 cells apparently form a converted SEI layer at low temperatures which acts as if it were a brittle layer which breaks down followed by a rapid healing process probably involving reduction of the electrolyte to form a new layer. These cells thus show

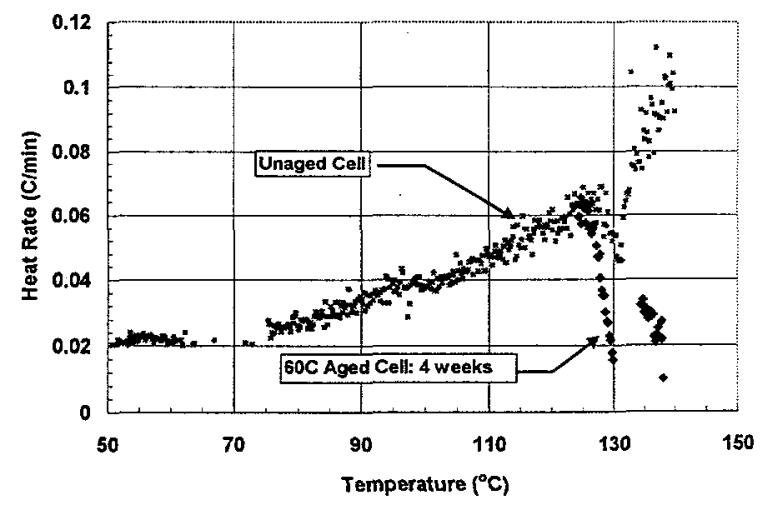

Figure 12. ARC results for aged GEN1 cell $100 \%$ SOC. 
greater thermal stability at low temperatures but may exhibit abrupt heating if forced to higher temperatures above $125^{\circ} \mathrm{C}$.

\section{CONCLUSIONS}

Calorimetric analysis has identified cell and component reactions in $\mathrm{Li}$-ion cells that contribute to the complex thermal response of these cells. Initial low-temperature reactions result from conversion of the anode SEI layer to more stable phases. This reaction can contribute to the initiation of thermal runaway in the cells. These cells were observed to become more unstable with increasing SOC. At temperatures approaching $200^{\circ} \mathrm{C}$ anode, cathode and electrolyte all contribute to the thermal output of the cell resulting in violent reaction. Aging results in reduced thermal output due to partial conversion of the anode SEI layer to more stable phases.

\section{ACKNOWLEDGEMENTS}

We acknowledge the support of DOE Office of Advanced Automotive Technology through the PNGV Advanced Technology Development (ATD) High Power Battery Development Program. Sandia National Laboratories is a multiprogram laboratory operated by Sandia Corporation, a Lockheed Martin Company, for the United States Department of Energy under contract DE-AC04-94AL85000.

\section{REFERENCES}

1. K. Ozawa, Solid State Ionics, 69, 212 (1994).

2. U. von Sacken, E. Nodwell, A. Sundher, and J. R. Dahn, J. Power Sources, 54, 240-245 (1995).

3. M. N. Richard and J. R. Dahn, J. Electrochem. Soc., 146 (6), 2068-2077 (1999).

4. M. N. Richard and J. R. Dahn, J. Electrochem. Soc., 146 (6), 2078-2084 (1999).

5. J. cho, H. Jung, Y. Park, G. Kim and H. S. Lim, J. Electrochem. Soc., 147 (1), 15-20 (2000). 